\title{
Effect of Change in Newborn's Position during Mechanical Ventilation on Oxygenation
}

\author{
Abdel Razek Mohammed Hefny Elshiekh, Atef Ibrahim Nosair, \\ Enas Mohammed Mahmoud Radwan Elshazly* \\ Pediatric Department, Faculty of Medicine, Zagazig University, Egypt \\ *Corresponding author: Enas Mohammed Mahmoud Radwan Elshazly, Pediatric ICU resident at \\ Zagazig General Hospital, Egypt, Telephone: (+20)01024683929, Email: mosad8rashed@ gmail.com
}

\begin{abstract}
Background: Acute respiratory failure remains an important cause of morbidity and mortality in children. In the last few years great attention was paid to the effect of changes in infant's position other than the supine position during mechanicall ventilation.

Objective: To evaluate the effect of position change on oxygenation in newborn infants during mechanical ventilation in neonatal intensive care unit (NICU).

Methods: This study was across- section study, which was done on 74 obese children aged 6-18 years. This study was done at Pediatrics Department, Zagazig University Hospitals, during the period from 2017 to 2018 . The cases were divided into two groups, group A included newborn infants using ventilators in supine position (supine group) and group B included newborn infants in supine position alternating with prone position (alternate group). All children were subjected to history talking and clinical examination. Anthropometric measurements were measured. In addition, carotid intima-media thickness quantification was estimated.

Results: There were statistically significant decrease in VT (ml) at ( $8 \mathrm{hr}$ and $16 \mathrm{hr}$ ) among alternate group than supine group. In addition, OI and $\mathrm{PaO}_{2}$, at 8 and $16 \mathrm{~h}$ in alternate position groups were higher than those in supine position group were. There were statistically significant decrease in PEEP $\left(\mathrm{cm} \mathrm{H}_{2} \mathrm{O}\right)$ at 8 hour among supine group than alternate group. There was no statistically significant difference between supine group and alternate group regarding PEEP $\left(\mathrm{cm} \mathrm{H}_{2} \mathrm{O}\right)$ at 16 hour. This study showed that, There were statistically significant decrease in $\mathrm{PaO}_{2}(\mathrm{~mm} \mathrm{Hg})$ at $(8 \mathrm{hr}$ and $1 \mathrm{hr}$ drawl) among supine group than alternate group. There was no statistically significant difference between supine group and alternate group regarding $\mathrm{PaO}_{2}(\mathrm{~mm} \mathrm{Hg})$ at $16 \mathrm{hr}$.

Conclusion: Oxygenation and respiratory mechanics were significantly improved in prone position group than those in supine position group. The physiological basis of prone positioning seems to act beneficially improving hemodynamics, gas exchange and respiratory mechanics.
\end{abstract}

Keywords: Newborn's Position - Mechanical ventilation-Oxygenation.

\section{INTRODUCTION}

Acute respiratory failure remains an important cause of morbidity and mortality in children. Cardiac arrests in children frequently result from respiratory failure. In 2014, data from the National Center for Health Statistics listed respiratory illnesses as one of the top 10 causes of pediatric mortality ${ }^{(1)}$. The introduction of mechanical ventilation in the $1960 \mathrm{~s}$ was one of the major new interventions in neonatology, which provided lifesaving support for infants with respiratory failure ${ }^{(2)}$.

In the last few years, great attention was paid to the effect of changes in infant's position other than the supine position during mechanicall ventilation (3). Prone positioning has been shown to improve oxygenation in extremely low-birth infants with chronic lung disease and in neonates with respiratory failure ${ }^{(4)}$.

\section{AIM OF THE WORK}

This study aimed to evaluate the effect of position change on oxygenation in newborn infants during mechanical ventilation in NICU.

\section{PATIENTS AND METHODS}

Present study was an experimental study, which carried out on all neonates (in first 28 days of life) admitted to neonatal intensive care unit (NICU) at Zagazig University Hospital. The study was comparative study between two groups where cases selected randomly. Group A included newborn infants using ventilators in supine position and group B included newborn infants in supine position alternating with prone position.

- Inclusion criteria: Newborn infants with confirmed respiratory failure.

- Exclusion criteria: Neonates with severe chest deformities, intolerance to prone position, increased intracranial tension, acute haemorrhage and pneumothorax or hemodynamically unstable.

\section{- Sample Size:}

Assuming that $\mathrm{PaO}_{2}$ in supine group after 8 hours was $60.13 \pm 8.95$ in supine group and $65.29 \pm 7.62$ in alternate group at confidence level $95 \%$, power $80 \%$ so, total sample size is 82 (41 in each group). 
Ethical approval:

Approval was taken from the Institutional Review Board (IRB) of Faculty of Medicine, Zagazig University.

* Written informed consent was obtained from all patients or caregiver.

* All the participating patients were subjected to the following:

History: Complete history taking including sex, age and birth weight.

Examination: Respiratory distress, difficult breathing and lethargy.

Data collected 8 and 16 hours in both groups included ventilator parameters $\left(\mathrm{FiO}_{2}, \mathrm{PIP}, \mathrm{PEEP}, \mathrm{RR}\right)$, lung mechanics [tidal volume (VT), minute ventilation $(\mathrm{VM})$, partial oxygen tension $\left(\mathrm{PaO}_{2}\right)$ and partial carbon dioxide tension $\left(\mathrm{PaCO}_{2}\right)$ ] and Oxygenation Index OI $\left(\mathrm{OI}=\left(\mathrm{PaO}_{2} \times \mathrm{FiO}_{2} /\right.\right.$ mean airway pressure $\left.) \times 100\right)$.
Mechanical ventilation withdrawal time, $\mathrm{PaO}_{2}$, and $\mathrm{PaCO}_{2}$ at 1 hour after draw.

Investigation: Laboratory investigations included $\mathrm{CBC}$ and CRP.

\section{Statistical analysis}

The data were coded, entered and processed on computer using SPSS (version 18). The results were represented in tabular and diagrammatic forms then interpreted. Mean, standard deviation, range, frequency, and percentage were use as descriptive statistics.

The following test were used: Chi-Square test was used to test the association variables for categorical data. Student's t-test was used to assess the statistical significance of the difference between two population means in a study involving independent samples. $\mathrm{P}$ value was considered significant as the following:

$* \mathrm{P}>0.05$ : Non-significant.

$* \mathrm{P} \leq 0.05$ : Significant

\section{RESULTS}

Table (1): Comparison between supine group and alternate positions group regarding demographic data

\begin{tabular}{|c|c|c|c|c|c|c|}
\hline & & & Supine group & $\begin{array}{c}\text { Alternate } \\
\text { group }\end{array}$ & t.test & P. value \\
\hline \multicolumn{2}{|c|}{ Age (days) } & Mean \pm SD & $1.28 \pm 1.09$ & $1.495 \pm 1.32$ & $-.775-$ & 0.440 \\
\hline \multicolumn{2}{|c|}{ Birth weight (kg) } & Mean \pm SD & $2.84 \pm 0.47$ & $2.824 \pm 0.489$ & .146 & 0.884 \\
\hline \multirow{4}{*}{ Sex } & Female & No. & 19 & 17 & \multirow{4}{*}{$\begin{array}{c}\mathbf{X}^{\mathbf{2}} \\
0.198\end{array}$} & \multirow{4}{*}{0.656} \\
\hline & remale & $\%$ & $46.3 \%$ & $41.5 \%$ & & \\
\hline & \multirow{2}{*}{ Male } & No. & 22 & 24 & & \\
\hline & & $\%$ & $53.7 \%$ & $58.5 \%$ & & \\
\hline
\end{tabular}

There was no statistically significant difference between supine group and alternate positions group regarding age (days), birth weight (kg) and Sex (Table 1).

Table (2): Comparison between supine group and alternate positions group regarding duration of MV (days)

\begin{tabular}{|c|c|c|c|c|c|}
\hline \multicolumn{2}{|c|}{} & $\begin{array}{c}\text { Supine group } \\
\text { (No.= 41) }\end{array}$ & $\begin{array}{c}\text { Alternate group } \\
(\text { No.= 41) }\end{array}$ & t.test & P. value \\
\hline $\begin{array}{c}\text { duration of MV } \\
\text { (days) }\end{array}$ & Mean \pm SD & $5.22 \pm 2.35$ & $9.05 \pm 19.98$ & $-1.218-$ & 0.227 \\
\hline
\end{tabular}

There was no statistically significant difference between supine group and alternate positions group regarding duration of MV (days) (Table 2).

Table (3): Comparison between supine group and alternate positions group regarding $\mathrm{FiO}_{2}(\%)$ at $8 \mathrm{hr}, 16 \mathrm{hr}$ and 1 hr draw

\begin{tabular}{|c|c|c|c|c|c|}
\hline \multicolumn{2}{|c|}{} & $\begin{array}{c}\text { Supine group } \\
(\text { No.= 41) }\end{array}$ & $\begin{array}{c}\text { Alternate group } \\
(\text { No.= 41) }\end{array}$ & t.test & P. value \\
\hline $\mathrm{FiO}_{\mathbf{2}}(\%)$ at $8 \mathrm{hr}$ & Mean \pm SD & $48.66 \pm 11.18$ & $43.29 \pm 11.92$ & 2.102 & 0.039 \\
\hline $\mathbf{F i O}_{2}(\%)$ at $16 \mathbf{~ h r}$ & Mean \pm SD & $40.37 \pm 11.20$ & $39.98 \pm 8.94$ & .174 & 0.862 \\
\hline $\begin{array}{c}\mathbf{F i O}_{2}(\%) \text { at } \mathbf{1 ~ h r} \\
\text { drawl }\end{array}$ & Mean \pm SD & $24.29 \pm 2.88$ & $24.39 \pm 2.78$ & $-.156-$ & 0.877 \\
\hline
\end{tabular}

There was statistically significant increase in $\mathrm{FiO}_{2}(\%)$ at $8 \mathrm{hr}$ among supine group than among alternate positions group. There was no statistically significant difference between supine group and alternate positions group regarding $\mathrm{FiO}_{2}(\%)$ at (16 hr and $1 \mathrm{hr}$ draw) (Table 3). 
Table (4): Comparison between supine group and alternate positions group regarding $\mathrm{PIP}\left(\mathrm{cm} \mathrm{H}_{2} \mathrm{O}\right)$ at $8 \mathrm{hr}$ and $16 \mathrm{hr}$

\begin{tabular}{||c|c|c|c|c|c||}
\hline \multicolumn{2}{|l|}{} & $\begin{array}{c}\text { Supine group } \\
(\text { No.= 41) }\end{array}$ & $\begin{array}{c}\text { Alternate group } \\
(\text { No.= 41) }\end{array}$ & t.test & P. value \\
\hline $\begin{array}{c}\text { PIP (cm Ho) at } \\
\mathbf{8} \text { hour }\end{array}$ & Mean \pm SD & $14.02 \pm 1.93$ & $15.12 \pm 1.73$ & $-2.708-$ & 0.008 \\
\hline $\begin{array}{c}\text { PIP(cm Ho) at } \\
\mathbf{1 6} \text { hour }\end{array}$ & Mean \pm SD & $14.05 \pm 2.29$ & $15.10 \pm 1.74$ & $-2.333-$ & 0.022 \\
\hline
\end{tabular}

There was statistically significant decrease in PIP $\left(\mathrm{cm} \mathrm{H}_{2} \mathrm{O}\right)$ at $(8 \mathrm{hr}$ and $16 \mathrm{hr})$ among supine group than among alternate positions group (Table 4).

Table (5): Comparison between supine group and alternate positions group regarding $\mathrm{PEEP}\left(\mathrm{cm} \mathrm{H}_{2} \mathrm{O}\right)$ at $8 \mathrm{hr}$ and $16 \mathrm{hr}$

\begin{tabular}{|c|c|c|c|c|c|}
\hline \multicolumn{2}{|c|}{} & $\begin{array}{c}\text { Supine group } \\
(\text { No.=41) }\end{array}$ & $\begin{array}{c}\text { Alternate group } \\
(\text { No.= 41) }\end{array}$ & t.test & P. value \\
\hline $\begin{array}{c}\text { PEEP (cm H2O) at } \\
\text { 8 hour }\end{array}$ & $\begin{array}{c}\text { Mean } \pm \\
\text { SD }\end{array}$ & $4.76 \pm 0.88$ & $5.20 \pm 0.813$ & $-2.335-$ & 0.022 \\
\hline $\begin{array}{c}\text { PEEP (cm H2O) at } \\
\text { 16 hour }\end{array}$ & $\begin{array}{c}\text { Mean } \pm \\
\text { SD }\end{array}$ & $4.90 \pm 0.831$ & $5.29 \pm 1.05$ & $-1.861-$ & 0.066 \\
\hline
\end{tabular}

There was statistically significant decrease in PEEP $\left(\mathrm{cm} \mathrm{H}_{2} \mathrm{O}\right)$ at 8 hour among supine group than among alternate positions group. There was no statistically significant difference between supine group and alternate positions group regarding PEEP $\left(\mathrm{cm} \mathrm{H}_{2} \mathrm{O}\right)$ at 16 hour (Table 5).

Table (6): Comparison between supine group and alternate positions position group regarding RR (times/min) at $8 \mathrm{hr}$, $16 \mathrm{hr}$ and $1 \mathrm{hr}$ draw

\begin{tabular}{|c|c|c|c|c|c|}
\hline & & $\begin{array}{c}\text { Supine group } \\
(\text { No. }=41)\end{array}$ & $\begin{array}{c}\text { Alternate group } \\
(\text { No.= 41) }\end{array}$ & t.test & P. value \\
\hline $\begin{array}{l}\text { RR (times/min) at } \\
8 \text { hour }\end{array}$ & Mean \pm SD & $43.63 \pm 5.87$ & $44.37 \pm 7.22$ & $-.503-$ & 0.616 \\
\hline $\begin{array}{c}\text { RR (times/min) at } \\
16 \text { hour }\end{array}$ & Mean \pm SD & $42.83 \pm 3.66$ & $43.10 \pm 6.449$ & $-.232-$ & 0.817 \\
\hline $\begin{array}{c}\text { RR (times/min) at } \\
1 \text { hour draw }\end{array}$ & Mean \pm SD & $41.22 \pm 5.68$ & $39 \pm 4.68$ & 1.785 & 0.079 \\
\hline
\end{tabular}

There was no statistically significant difference between supine group and alternate positions group regarding RR (times/min) at $8 \mathrm{hr}, 16 \mathrm{hr}$ and $1 \mathrm{hr}$ draw (Table 6).

Table (7): Comparison between supine group and alternate positions group regarding VT (ml) at $8 \mathrm{hr}$ and $16 \mathrm{hr}$

\begin{tabular}{|c|c|c|c|c|c|}
\hline \multicolumn{2}{|l|}{} & $\begin{array}{c}\text { Supine group } \\
(\text { No.= 41) }\end{array}$ & $\begin{array}{c}\text { Alternate group } \\
(\text { No.= 41) }\end{array}$ & t.test & P. value \\
\hline VT(ml) at 8 hr & Mean \pm SD & $5.75 \pm 1.13$ & $4.89 \pm 0.32$ & 4.686 & 0.000 \\
\hline VT(ml) at $\mathbf{1 6}$ hr & Mean \pm SD & $5.77 \pm 0.91$ & $5.08 \pm 0.29$ & 4.633 & 0.000 \\
\hline
\end{tabular}

There was statistically significant increase in VT $(\mathrm{ml})$ at $8 \mathrm{hr}$ and $16 \mathrm{hr}$ among supine group than among alternate positions group (Table 7).

Table (8): Comparison between supine group and alternate positions group regarding MV (RR*VT) (ml/min) at 8 hr and $16 \mathrm{hr}$

\begin{tabular}{|c|c|c|c|c|c|}
\hline \multicolumn{2}{|c|}{} & $\begin{array}{c}\text { Supine group } \\
(\text { No.= 41) }\end{array}$ & $\begin{array}{c}\text { Alternate group } \\
(\text { No.= 41) }\end{array}$ & t.test & $\begin{array}{c}\text { P. } \\
\text { value }\end{array}$ \\
\hline $\begin{array}{c}\text { MV (RR*VT) } \\
(\mathbf{m l} / \mathbf{m i n}) \text { at 8 hr }\end{array}$ & Mean + SD & $248.55 \pm 56.37$ & $217.54 \pm 41.62$ & 2.833 & 0.006 \\
\hline $\begin{array}{c}\text { MV (RR*VT) } \\
(\mathbf{m l} / \mathbf{m i n}) \text { at 16 hr }\end{array}$ & Mean + SD & $239.04 \pm 47.89$ & $220.35 \pm 35.03$ & 2.017 & 0.047 \\
\hline
\end{tabular}

There was statistically significant increase in MV (RR*VT) (ml/min) at $8 \mathrm{hr}$ and $16 \mathrm{hr}$ among supine group than among alternate positions group (Table 8). 
Table (9): Comparison between supine group and alternate positions group regarding $\mathrm{PaO}_{2}(\mathrm{~mm} \mathrm{Hg})$ at $8 \mathrm{hr}, 16 \mathrm{hr}$ and $1 \mathrm{hr}$ drawl

\begin{tabular}{|c|c|c|c|c|c|}
\hline & & $\begin{array}{l}\text { Supine group } \\
(\text { No. }=41)\end{array}$ & $\begin{array}{l}\text { Alternate group } \\
(\text { No. }=41)\end{array}$ & t.test & $\begin{array}{c}P . \\
\text { value }\end{array}$ \\
\hline $\begin{array}{c}\mathrm{PaO}_{2}(\mathrm{~mm} \mathrm{Hg}) \text { at } \\
8 \mathrm{hr} \\
\end{array}$ & Mean \pm SD & $40.36 \pm 30.03$ & $66.83 \pm 45.14$ & $-3.125-$ & 0.002 \\
\hline $\begin{array}{c}\mathrm{PaO}_{2}(\mathrm{~mm} \mathrm{Hg}) \text { at } \\
16 \mathrm{hr}\end{array}$ & Mean \pm SD & $71.51 \pm 55.38$ & $76.61 \pm 50.64$ & $-.435-$ & 0.665 \\
\hline $\begin{array}{c}\mathrm{PaO}_{2}(\mathrm{~mm} \mathrm{Hg}) \text { at } \\
1 \text { hr draw }\end{array}$ & Mean \pm SD & $46.317 \pm 36.05$ & $91.91 \pm 62.92$ & $-4.026-$ & 0.000 \\
\hline
\end{tabular}

There was no statistically significant difference between supine group and alternate positions group regarding $\mathrm{PaO}_{2}$ $(\mathrm{mm} \mathrm{Hg})$ at $16 \mathrm{hr}$. There was statistically significant decrease in $\mathrm{PaO}_{2}(\mathrm{~mm} \mathrm{Hg})$ at $8 \mathrm{hr}$ and $1 \mathrm{hr}$ draw among supine group than among alternate positions group (Table 9).

Table (10): Comparison between supine group and alternate position group regarding $\mathrm{PaCO}_{2}(\mathrm{~mm} \mathrm{Hg})$ at $8 \mathrm{hr}, 16 \mathrm{hr}$ and $1 \mathrm{hr}$ draw

\begin{tabular}{|c|c|c|c|c|c|}
\hline & & $\begin{array}{c}\text { Supine group } \\
(\text { No. }=41)\end{array}$ & $\begin{array}{l}\text { Alternate group } \\
(\text { No. }=41)\end{array}$ & t.test & P. value \\
\hline $\begin{array}{c}\mathrm{PaCO}_{2}(\mathrm{~mm} \\
\mathrm{Hg}) \text { at } 8 \mathrm{hr}\end{array}$ & Mean \pm SD & $36.02 \pm 12.13$ & $39.09 \pm 11.08$ & $-1.195-$ & 0.236 \\
\hline $\begin{array}{l}\mathrm{PaCO}_{2}(\mathrm{~mm} \\
\mathrm{Hg}) \text { at } 16 \mathrm{hr}\end{array}$ & Mean \pm SD & $33.24 \pm 15.05$ & $34.77 \pm 9.66$ & -.548 & 0.585 \\
\hline $\begin{array}{c}\mathrm{PaCO}_{2}(\mathrm{~mm} \\
\mathrm{Hg}) \text { at } 1 \mathrm{hr} \\
\text { draw }\end{array}$ & Mean \pm SD & $40.27 \pm 10.10$ & $41.96 \pm 9.65$ & $-.777-$ & 0.440 \\
\hline
\end{tabular}

There was no statistically significant difference between supine group and alternate group regarding $\mathrm{PaCO}_{2}(\mathrm{~mm} \mathrm{Hg})$ at $8 \mathrm{hr}, 16 \mathrm{hr}$ and $1 \mathrm{hr}$ draw (Table 10).

Table (11): Comparison between supine group and alternate positions group regarding $\mathrm{OI}\left(\mathrm{PaO}_{2} / \mathrm{FiO}_{2}\right)$ at $8 \mathrm{hr}, 16 \mathrm{hr}$ and $1 \mathrm{hr}$ draw

\begin{tabular}{|c|c|c|c|c|c|}
\hline & & $\begin{array}{l}\text { Supine group } \\
(\text { No.= 41) }\end{array}$ & $\begin{array}{l}\text { Alternate group } \\
\text { (No.=41) }\end{array}$ & t.test & $\begin{array}{c}P . \\
\text { value }\end{array}$ \\
\hline $\begin{array}{c}\mathrm{OI}\left(\mathrm{PaO}_{2} / \mathrm{FiO}_{2}\right) \\
\text { at } 8 \mathrm{hr} \\
\end{array}$ & Mean \pm SD & $87.21 \pm 64.82$ & $156.06 \pm 103.37$ & $-3.613-$ & 0.001 \\
\hline $\begin{array}{c}\mathrm{OI}\left(\mathrm{PaO}_{2} / \mathrm{FiO}_{2}\right) \\
\text { at } 16 \mathrm{hr}\end{array}$ & Mean \pm SD & $177.42 \pm 159.47$ & $203.18 \pm 125.68$ & $-.813-$ & 0.419 \\
\hline $\begin{array}{c}\mathrm{OI}\left(\mathrm{PaO}_{2} / \mathrm{FiO}_{2}\right) \\
\text { at } 1 \mathrm{hr} \text { drawl }\end{array}$ & Mean \pm SD & $195.06 \pm 158.84$ & $375.07 \pm 288.69$ & $-3.498-$ & 0.001 \\
\hline
\end{tabular}

There was no statistically significant difference between supine group and alternate positions group regarding OI $\left(\mathrm{PaO}_{2} / \mathrm{FiO}_{2}\right)$ at $16 \mathrm{hr}$. There was statistically significant decrease in $\mathrm{OI}\left(\mathrm{PaO}_{2} / \mathrm{FiO}_{2}\right)$ at $8 \mathrm{hr}$ and $1 \mathrm{hr}$ draw among supine group than among alternate positions group (Table 11).

\section{DISCUSSION}

This study demonstrated that, there were no statistically significant difference between supine group and alternate group regarding sex, age (days), birth weight $(\mathrm{kg})$ and duration of MV (days).

This study showed that there were statistically significant decrease in VT (ml) at $8 \mathrm{hr}$ and $16 \mathrm{hr}$ among alternate group than among supine group. In addition, $\mathrm{OI}$ and $\mathrm{PaO}_{2}$, at 8 and $16 \mathrm{~h}$ in alternate position group were higher than those in supine position group were. This indicated that the oxygenation and respiratory mechanics were significantly improved in alternate position group than those in supine position group, and the improvement was enhanced over time as was

reported.

Currently recognized view about ventilation in dorsal position is to improve the ratio of ventilation/blood flow (V/Q) and reduce pulmonary shunt (intrathoracic pressure gradually decreases along the direction of gravity from upside to downside, or even becomes positive pressure). In the case of respiratory failure, the positive intrathoracic pressure in most prolapse area was so large that no adequate negative pressure was produced at the end of inhalation leading to alveolar collapse in the prolapse area. Ventilation in dorsal position resulted in large 
sternum diaphragmatic mobility in the sternum side, most VT in the sternum side and few blood flows. Several blood flows in the dorsal side and few air flows lead to increased shunt and more unreasonable V/Q ratio ${ }^{(5)}$.

Ventilation in prone position resulted in gradient decrease in the gravity distribution of intrapleural pressure, which was even from upside to downside. Transpulmonary pressure was also even so that the previously collapsed alveoli in dorsal lung could redilate. The ventilation throughout the lung was even, with matched V/Q and reduced shunt; as a result, the oxygenation was improved ${ }^{(6)}$.

The improvement in the respiratory mechanics may be related to the thoracic stability in breath and the motion amplitude of the diaphragm. In dorsal position, the heart oppressed the lung tissue directly in the dorsal side of chest wall, while in the prone position, the heart weight oppressed the sternum, thus helped relieve the oppression of lung tissue in the dorsal side of the sternum by the heart, and improved ventilation in local lung tissue and blood perfusion ${ }^{(7)}$.

Prone position can improve oxygenation and save time for the treatment. Gattinoni et al. ${ }^{\left({ }^{(8)}\right.}$ reported that the survival of severe Acute respiratory distress syndrome ( ARDS) patients could be increased significantly in prone position. Recently, a controlled study report in France Croix-Rousse Hospital ICU, suggested that the ventilation in prone position for $12 \mathrm{~h}$ daily could significantly decrease the mortality in severe ARDS patients $\left(\mathrm{PaO}_{2} / \mathrm{FiO}_{2}<150 \mathrm{~mm} \mathrm{Hg}\right.$, $\mathrm{FiO}_{2} \geq 0.5$ and $\mathrm{PEEP} \geq 5 \mathrm{~cm} \mathrm{H}_{2} \mathrm{O}$ for $12-24 \mathrm{~h}$ ). This report also indicated that severe ARDS patients should receive ventilation in prone position as soon as possible. Appropriate extended duration of the ventilation in prone position could improve the prognosis ${ }^{(4)}$. These results are in agreement with our results.

This study showed that, there were statistically significant decrease in PEEP $\left(\mathrm{cm} \mathrm{H}_{2} \mathrm{O}\right)$ at 8 hour among supine group than among alternate group. There was no statistically significant difference between supine group and alternate group regarding PEEP $\left(\mathrm{cm} \mathrm{H}_{2} \mathrm{O}\right)$ at 16 hour. It is worth to mention that the interaction between PEEP and posture on regional distribution of ventilation was recently examined in anesthetized human volunteers. It was found that after the addition of PEEP in the prone position there is a much greater redistribution to ventral areas for blood flow than for ventilation, causing increased V/Q mismatch. In the study of Petersson et al. ${ }^{(9)}$, without PEEP, the vertical ventilation-to-perfusion gradient was less in prone postures than in supine, but with PEEP, the gradient was similar. Although this finding supports prior studies, which have shown that lower PEEP is needed to maintain oxygenation in the prone posture than in the supine ${ }^{(\mathbf{1 0})}$, reductions of PEEP are inappropriate, at least when $\mathrm{V} / \mathrm{Q}$ matching and systemic oxygenation are being evaluated ${ }^{(11)}$.

There was no statistically significant difference between supine group and alternate group regarding $\mathrm{PaCO}_{2}(\mathrm{~mm} \mathrm{Hg})$ at $8 \mathrm{hr}, 16 \mathrm{hr}$ and $1 \mathrm{hr}$ draw. The $\mathrm{CO}_{2}$ clearance is becoming impaired due to structural changes of the lung ${ }^{(\mathbf{1 2})}$ and the increase in dead space proves to be a prognostic marker of ARDS mortality (13). Interestingly, turning the ARDS patient to prone position does not always result in decrease in arterial $\mathrm{CO}_{2}$ because the presence of aerated alveoli does not necessarily mean that they are also well ventilated. In fact, it has been suggested that oxygen and carbon dioxide responses to prone position are independent and a decrease in $\mathrm{PaCO}_{2}$ to the first pronation rather than an increase in $\mathrm{PaO}_{2} / \mathrm{FiO}_{2}$, is significantly associated with lung recruitability and a better outcome (14). It has been proposed that in $\mathrm{PaCO}_{2}$ nonresponders, the primary mechanism of the $\mathrm{PaO}_{2}$ increase is diversion of the blood flow, whereas in $\mathrm{PaCO}_{2}$ responders the primary mechanism is greater dorsal recruitment in comparison to ventral derecruitment, combined with reduced alveolar overinflation (15). The $\mathrm{PaCO}_{2}$ responders seem to have a higher potential to be recruited with prone positioning than with nonresponders, revealing a difference in underlying lung pathologies ${ }^{(16)}$. It has also been suggested that when $\mathrm{PaO}_{2}$ increases and $\mathrm{PaCO}_{2}$ does not simultaneously decrease, it is a sign that either cardiac output is lowered or alveolar dead space ventilation is increased by PEEP, reflecting lung overdistention ${ }^{(17)}$.

This study showed that, There were statistically significant decrease in $\mathrm{PaO}_{2}(\mathrm{~mm} \mathrm{Hg})$ at $8 \mathrm{hr}$ and $1 \mathrm{hr}$ draw among supine group than among alternate group. There was no statistically significant difference between supine group and alternate group regarding $\mathrm{PaO}_{2}(\mathrm{~mm} \mathrm{Hg})$ at $16 \mathrm{hr}$. Yao et al. (18) showed that preterm infants 1 and 6 hours after weaning from mechanical ventilation had a higher $\mathrm{PaO}_{2}$ in prone position compared to supine position. Abdeyazdan et al. (19) results showed that in prone position the mean of $\mathrm{SPO}_{2}$ was significantly higher than in supine position. However, in this study, unlike Yao's study, assessing the tissue oxygenation was conducted using pulse oxymeter and the infants underwent mechanical ventilation at the time of intervention and at their first week of post natal. The present study was in accordance with study of Chang et al. (20) regarding the study population and method of infants' evaluation and results.

Oxygenation: It is well known that there is normally a regional difference in intrapleural pressure, being more subatmospheric at the apex and at the nondependent lung areas. This is clearly a gravity dependent phenomenon and results in exponentially regional differences in transpulmonary pressure and 
thus in the size of alveoli. The transpulmonary pressure, i.e. the distending forces of the lung, decreases along the ventral-to-dorsal axis and the size of the alveolar units decreases toward the dependent areas. It was found that by turning the patient to the prone position due to thoracic-lung shape modifications of the intrapleural pressure becomes less negative in non-dependent and less positive in dependent regions (21). The net effect of prone positioning is not only the increase of regional inflation distribution in dorsal regions and decrease in ventral regions respectively, but intrapleural pressure, transpulmonary pressure and regional inflation distribution become more homogeneous throughout the lung ${ }^{(22)}$. It was early suggested that this could be explained by the reversal of lung weight gradients, the direct transmission of the weight of the heart to subjacent regions, direct transmission of the weight of abdominal contents to caudal regions of the dorsal lung and/or regional mechanical properties and shape of the chest wall and lung ${ }^{(23)}$.

\section{CONCLUSION}

- Oxygenation and respiratory mechanics were significantly improved in prone position group than those in supine position group.

- The physiological basis of prone positioning seems to act beneficially improving hemodynamics, gas exchange and respiratory mechanics.

Conflict of interest: The authors declare no conflict of interest.

Funding sources: The authors have no funding to report

\section{REFERENCES}

1. Wu J, Zhai J, Jiang $\mathrm{H}$ et al. (2015): Effect of Change of Mechanical Ventilation Position on the Treatment of Neonatal Respiratory Failure. Cell Biochem Biophys., 72: 845-852.

2. Kennedy KA, Cotten CM, Watterberg KL et al. (2016): Prevention and management of bronchopulmonary dysplasia: Lessons learned from the neonatal research network. Seminars in Perinatology, 40 (6): 348-355.

3. Setten M, Plotnikow G, Accoce M (2016): Prone position in patients with acute respiratory distress syndrome. Decúbito prono en pacientes con síndrome de distrés respiratorio agudo. Revista Brasileira de Terapia Intensiva, 28 (4): 452-462.

4. Guérin C, Reignier J, Richard J et al. (2013): Prone positioning in severe acute respiratory distress syndrome. N Engl J Med., 368: 2159-2168.

5. Yu S (2008): Clinical practice of mechanical ventilation [M]. Beijing: People's Military Medical Press. https://europepmc.org/article/med/25647746

6. Roche-Campo F, Aguirre-Bermeo H, Mancebo J (2011): Prone positioning in acute respiratory distress syndrome
(ARDS): When and how ? Presse Medicale, 40 (12 Pt 2): 585594.

7. Albert RK, Hubmayr RD (2000): The prone position eliminates compression of the lungs by the heart [J]. American Journal of Respiratory and Critical Care Medicine, 161 (5): 1660-1665.

8. Gattinoni L, Protti A, Caironi P et al. (2010): Ventilatorinduced lung injury: the anatomical and physiological framework. Crit Care Med., 38: 539-548.

9. Petersson J, Ax M, Frey J et al. (2016): Positive endexpiratory pressure redistributes regional blood flow and ventilation differently in supine and prone humans. Anesthesiology, 113: 1361-1369.

10. Gainnier M, Michelet $P$, Thirion $X$ et al. (2003): Prone position and positive end-expiratory pressure in acute respiratory distress syndrome. Crit Care Med., 31: 27192726.

11. Gattinoni L, Caironi $P$ (2010): Prone positioning: beyond physiology. Anesthesiology, 113: 1262-1264.

12. Guerin C, Gaillard S, Lemasson S et al. (2004): Effects of systematic prone positioning in hypoxemic acute respiratory failure: a randomized controlled trial. JAMA., 292: 2379-2387.

13. Kallet RH, Alonso JA, Pittet JF et al. (2004): Prognostic value of the pulmonary dead-space fraction during the first 6 days of acute respiratory distress syndrome. Respir Care, 49: 1008-1014.

14. Protti A, Chiumello D, Cressoni M et al. (2009): Relationship between gas exchange response to prone position and lung recruitability during acute respiratory failure. Intensive Care Med., 35: 1011-1017.

15. Gattinoni L, Pesenti A, Carlesso E (2013): Body position changes redistribute lung computed-tomographic density in patients with acute respiratory failure: impact and clinical fallout through the following 20 years. Intensive Care Med., 39: 1909-1915.

16. Dirkes S, Dickinson S, Havey $R$ et al. (2012): Prone positioning: is it safe and effective? Crit Care Nurs Q., 35: 64-75.

17. Guérin $\mathbf{C}$ (2006): Ventilation in the prone position in patients with acute lung injury/acute respiratory distress syndrome. Curr Opin Crit Care, 12: 50-54.

18. Yao WX, Xue XD, Fu JH (2008): Effect of position on oxygenation in neonates after weaning from mechanical ventilation. Zhongguo Dang Dai Er Ke Za Zhi., 10 (2): 1214.

19. Abdeyazdan, $Z$, Nematollahi, M, Ghazavi, $Z$ et al. (2010): The effects of supine and prone positions on oxygenation in premature infants undergoing mechanical ventilation. Iranian Journal of Nursing and Midwifery Research, 15 (4): 229-233.

20. Chang YJ, Anderson GC, Dowling D et al. (2002): Decreased activity and oxygen desaturation in prone ventilated preterm infants during the first postnatal week. Heart Lung, 31 (1): $34-42$.

21. Guerin C, Baboi L, Richard JC (2014): Mechanisms of the effects of prone positioning in acute respiratory distress syndrome. Intensive Care Med., 40: 1634-1642.

22. Guérin C (2014): Prone ventilation in acute respiratory distress syndrome. Eur Respir Rev., 23: 249-257.

23. Pelosi P, Brazzi L, Gattinoni L (2002): Prone position in acute respiratory distress syndrome. Eur Respir J., 20: 1017-1028. 